\title{
A New Postulate for Using the Harmony in Gradation to Finding the Theory of Everything
}

\author{
Sigit Haryadi \\ Institut Teknologi Bandung, December 2018
}

\section{Paper DOI 10.31227/osf.io/2rak6}

\section{Citations}

APA: Haryadi, S. (2018, December 12). A New Postulate for Using the Harmony in Gradation to Finding the Theory of Everything. Retrieved from osf.io/preprints/inarxiv/2rak6

MLA: Haryadi, Sigit. "A New Postulate for Using the Harmony in Gradation to Finding the Theory of Everything." INA-Rxiv, 12 Dec. 2018. Web.

Chicago: Haryadi, Sigit. 2018. "A New Postulate for Using the Harmony in Gradation to Finding the Theory of Everything." INA-Rxiv. December 12. osf.io/preprints/inarxiv/2rak6.

\begin{abstract}
The paper promotes a new postulate, so that the Harmony in Gradation, a concept that I promote to become the Formula for Everything, can be used to find the theory of everything. In detail, the postulate is "There cannot be a perfect equilibrium of a pair of objects in a union if we do not consider all objects in the union".
\end{abstract}

\section{Preface}

The paper promotes a new postulate, so that the Harmony in Gradation, a concept that I promote to become the Formula for Everything, can be used to find the theory of everything. In detail, the postulate is "There cannot be a perfect equilibrium of a pair of objects in a union if we do not consider all objects in the union".

In essence, I dare to propose that the Harmony in Gradation be used immediately in all branches of science because the existence of "the harmony" and "the gradation" at the same time when a formula is used to analyze a Union or a random variable is to produce an index or level that accurately and precisely represents the "harmony level" of the Union or random variable regardless of the population. This means that an index equal to one is showing the perfect conditions of the harmony level, a value equal to 0.95 means that the harmony level is 0.95 of the perfect, a value equal to 0.75 indicates the harmony level is equal to 0.75 of the perfect, and so on. The consequence, the Harmony in Gradation will produce an index that represents the nature of the union or the random variable very accurately and precisely. 
The branch of science that is worth considering the use of Harmony in Gradation is that it uses "the level of harmony" which represents "the beauty" as the keyword of the research, which in each branch of science are called in different terms such as "level of balance", "equilibrium level”, "stability level”, "level of parity", “equipoise level”, "level of competition", "level of justice", “fairness level”, "level of correlation”, “entropy”, "level of performance”, "Level of quality", "level of certainty", "level of health", "level of similarity", "confidence level”, "level of consistency", "level of equity", "level of equality", and others. And, don't forget, since some branches of science prefer to use the negative of these terms, then the spirit of Harmony in Gradation also corresponds to the terms of "the level of imbalance", "the level of concentration", "the level of injustice", "unfairness level", "complement level", "counterbalance level”, "level of uncertainty", "level of relativity", "level of inequality", "level of inequity", and others.

As I have explained, I propose three ways to Implement Harmony in Gradation as follows: First, is to replace the existing formula; second, the Harmony in Gradation formula is used to calculate "the harmony level" of the union or random variables that are being observed, which are formed or defined through an existing formula or a formula that was just made; and third, the spirit of Harmony in Gradation is utilized, in the sense that the existing formula is modified in such a way so that in the same time it has the two elements which "the Harmony" and "the Gradation".

Then, on my website Harmony in Gradation: The Formula for Everything and in my papers, I have explained that the Harmony in Gradation formula can be directly used to replace some existing formulas such as the Herfindahl Index, Gini Index, Pearson Correlation, and Emotion Consistency Formula by Pauli \& Kraepelin and others. Besides that, I have also explained how to revise the existing formula, which the Information Entropy formula of Shannon, so that the existing formula which only contains the Harmony component then changes to own at the same time the Harmony and the Gradation. Then, I also explained how to use the Harmony in Gradation to measure equilibrium in physics.

However, I have just learned how to use the Harmony in Gradation to find the Theory of Everything (TOE) that was aspired to by Physics and Astronomy experts for decades, and at the initial stage, I discovered that the first step is that we should make a new postulate.

Here, I tried to explain the new postulate, hoping to help the Physics and Astronomy experts to quickly find the Theory of Everything since at this moment I thought that I could not find it. 


\section{The Postulate}

"There cannot be a perfect equilibrium of a pair of objects in a union if we do not consider all objects in the union".

\section{Proposed Ways to Use the Postulate}

Some examples of implementing the postulate are:

I. When we are learning the nature or property of celestial objects in the universe, where we are in a situation that until now we still don't know the existence of all celestial objects in the universe, which means we cannot be in a state of perfect equilibrium, no matter how small the imbalance is, then it is obligatory for the use of a formula which contains both elements of "the Harmony" and "the Gradation". Vice versa, if we use a formula that only contains one of the Harmony or the Gradation, then there are two types of errors that will occur, the first is a very small error, sometimes can negligible when calculating the property of a celestial body in the form of a planet or star, and the second is a big mistake when interpreting the nature of the universe.

II. When we are observing an object by applying Newton's classical physical law "the magnitude of the reaction force of an object is the same as the force of action of the object", where we often ignore the forces of many objects that we consider small, this shows that we have erroneously made the assumption that there has been perfect equilibrium in the system we observe. In other words, the formula we use should not only consist of one of the Harmony or the Gradation, but must involve both. Vice Versa, there will be a wrong conclusion.

III. When we are observing a moving object by applying the law of special relativity, where the existing formula derived by Lorenz only observes a system consisting of one light that moves at the speed of $\mathrm{c}$ and one object that moves at the speed $\mathrm{v}$, even though in the real world conditions it must be very many objects that do not belong to our observation object that move at speeds of v1, v2, and so on and also many other lights that move at the speed of $\mathrm{c} / \mathrm{n} 1, \mathrm{c} / \mathrm{n} 2$ and so on. Thus, the act of not involving the whole objects and lights in the universe shows that equilibrium cannot be perfect. Then, the formula we use should not only consist of one of the Harmony or the Gradation, but must involve both. Vice Versa, there will be significantly wrong conclusions. Another possibility that must be considered is that the formula for the dilation of time and length derived by Lorenz is not experienced by the moving objects with velocity $\mathrm{v}$, but precisely experienced by the light or anything that has the light-like nature moving at $\mathrm{c}$ 
or very close to c which "lives itself" and does not affect the surrounding environment. Thus, the lights can be assumed as a separate union whose members are themselves in the form as an object and in the form of a wave. So, a perfect equilibrium can occur in the light itself. Moreover, following the quantum theory, then the light causes itself to have a time and length dilation which the amount does not depend on all objects around it. Thus, the process of special relativity can be explained as follows: the occurrence of changes in the frequency experienced by light in its form as a wave is related to causation with the dilation of time experienced by light in its form as an object and/or the changes in the wavelength of light in its form as a wave, if it occurs, is correlated with changes in the length of light in its shape as objects.

\section{Notes}

In order to understand the concept of "Haryadi Index" or "Harmony in Gradation" that became the spirit of this calculator, please read my writings in the following bibliography.

\section{References}

[1] Haryadi, S. (2018, December 6). The Fundamental of Harmony in Gradation, the Formula for Everything. Retrieved from osf.io/preprints/inarxiv/z2rvj

[2] Haryadi, Sigit. 2018. "Always Move to Seek Perfection: The New Equilibrium Index Calculation for the Science of Physics and Astronomy." INA-Rxiv. July 13. osf.io/preprints/inarxiv/8hrnb.

[3] Sigit Haryadi. (2017). Haryadi Index and Its Applications in Science of Law, Sociology, Economics, Statistics, and Telecommunications. Penerbit Elex Media Komputindo. Jakarta. ISBN: 978-602-02-9895-5.

[4]Sigit Haryadi. (2017). Indeks Haryadi dan Penerapan di Ilmu Hukum, Sosiologi, Ekonomi, Statistik, dan Telekomunikasi. Penerbit Elex Media Komputindo, Jakarta. ISBN: 978-602-029896-2

[5] Sigit Haryadi. (2016). Haryadi Index for Competition, Equality and Correlation Evaluation. Penerbit Lantip Safari Media, Bandung, Indonesia. ISBN: 978-602-73231-3-2

[6] Sigit Haryadi. (2016). Haryadi Index untuk Evaluasi Kompetisi, Kesetaraan dan Korelasi. Penerbit Lantip Safari Media, Bandung, Indonesia. ISBN: 978-602-73231-3-1

[7] Haryadi, S. (2018, March 29). Estimasi Cerdas Ver-H.1.0. http://doi.org/10.17605/OSF.IO/DHQ9Y

[8] Haryadi, S. (2018, March 29). Smart Estimation Ver-H.1.0. http://doi.org/10.17605/OSF.IO/2TYQK

[9] Sigit Haryadi. (March 17, 2018). The Six 100-year-old Formula Should be Replaced. Researchgate. DOI 10.13140/RG.2.2.21919.66723

[10] Haryadi, S. (2018, March 17). Sepuluh Implementasi Yang Pertama untuk Membuktikan bahwa "The Harmony in Gradation" adalah "The Formula Everything". Retrieved from osf.io/preprints/inarxiv/ja9ve

[11] Haryadi, S. (2018, March 17). The Ten First Implementations to prove that "The Harmony in Gradation" is "The Formula Everything". Retrieved from osf.io/preprints/inarxiv/59szb 
[12] Haryadi, S., \& California, S. H. (2018, March 14). New Method to Calculate the Level of Consistency of the Pauli \& Kraepelin Tests. Retrieved from osf.io/preprints/inarxiv/ty326

[13] Haryadi, S., \& California, S. H. (2018, March 14). Metoda Baru Untuk Menghitung Tingkat Konsistensi pada Tes Pauli \& Kraepelin. Retrieved from osf.io/preprints/inarxiv/qht8j [14] Haryadi, S. (2018, March 6). Calculation the Equity Level of an Internet Service. Retrieved from osf.io/uzcmq

[15] Haryadi, S. (2018, March 6). Perhitungan Tingkat Pemerataan Layanan Internet. Retrieved from osf.io/preprints/inarxiv/rgct3

[16] Dyah Rakhma Ariyanti; Sigit Haryadi. (October 2017). Analysis of Harmony In Gradation Index on 5G Cellular Network Quantitative Analysis. The 11th International Conference on Telecommunication Systems, Services, and Applications, At Lombok, Indonesia.

[17] Haryadi, S. (2017, November). Probabilitas Statistik Untuk Insinyur. Researchgate. DOI: 10.13140/RG.2.2.14304.58885

[18] Haryadi, S. (2018, February 1). Indeks Haryadi dan Prospeknya Untuk Menjadi Suatu "Formula of Everything (versi 31 Desember 2017). Retrieved from osf.io/zex45

[19] Haryadi, S. (2018, February 1). KALKULATOR untuk membuat Regresi Linier Tanpa Intersep. Retrieved from osf.io/emvs7

[20] Haryadi, S. (2018, February 1). Kalkulator Untuk Mengukur Tingkat Kompetisi di suatu Industri, dengan menggunakan rumus Indeks Haryadi. Retrieved from osf.io/fy7zu

[21] Haryadi, S. (2018, February 17). Calculation the Competition Levels between Students in Class and the Relation to the Teacher or Lecture Fairness in Teaching. Researchgate. DOI: 10.13140/RG.2.2.30359.06569

[22] Haryadi, S. (2018, February 17). Perhitungan Tingkat Kompetisi antar Murid atau Mahasiswa di Kelas dan Kaitannya Dengan Keadilan Guru atau Dosen Dalam Mengajar. Retrieved from osf.io/a894w

[23] Haryadi, S. (2018, February 22). Equality Correlation Calculation. Researchgate. DOI: 10.13140/RG.2.2.22068.76168

[24] Haryadi, S. (2018, February 22). Kalkulator Untuk Menghitung Korelasi Kesetaraan. Retrieved from osf.io/preprints/inarxiv/7r9jy

[25] Haryadi, S. (2018, February 24). Calculation of "Channel Cavity" on Data Communications. Equality Correlation Calculation. Research gate. DOI: 10.13140/RG.2.2.30536.01288

[26] Haryadi, S. (2018, February 24). Perhitungan "Rongga Kanal” pada Komunikasi Data. Retrieved from osf.io/preprints/inarxiv/y3wcg

[27] Haryadi, S. (2018, February 28). Ikhtisar Organisasi Regulasi Telekomunikasi. Retrieved from osf.io/preprints/inarxiv/g9m3k

[28] Haryadi, S. (2018, February 7). Statistik Terapan: Pengujian Regulasi \& Kebijakan Telekomunikasi. Retrieved from osf.io/3pkfw

[29] Haryadi, S. (2018, January 25). Chapter 1. The Concept of Telecommunication Network Performance and Quality of Service. Retrieved from osf.io/mukqb

[30] Haryadi, S. (2018, January 26). Chapter 2 of Network Performance and Quality of Service: Determination of Key Performance Indicator (KPI). Retrieved from osf.io/preprints/inarxiv/6gtnd

[31] Haryadi, S. (2018, January 26). Chapter 3 of Network Performance and Quality of Service: Technical Measurement of a Mobile Network Performance and Quality of Service. Retrieved from osf.io/q4wsz 
[32] Haryadi, S. (2018, January 30). Basic Calculation of the Network's Availability and Reliability (Chapter 4 of Network Performance and Quality of Service). Retrieved from osf.io/preprints/inarxiv/z5mwq

[33] Haryadi, S. (2018, March 1). Kebijakan Lisensi Telekomunikasi. Retrieved from osf.io/7wbjf

[34] Haryadi, S. (2018, March 5). Performance Measurement of Internet Service. Retrieved from osf.io/9nsw3

[35] Haryadi, S., \& Riani, W. (2018, March 5). METODE PENETAPAN TARIF PAJAK PENGHASILAN YANG BERKEADILAN. Retrieved from osf.io/preprints/inarxiv/ayg58

[36] Nie Levin Kusuma Adiatma ; Sigit Haryadi. (2017, October). Comparison of the Haryadi Index with Existing Method in Competition, Equality, Fairness, and Correlation Level Calculation Case Study: Telecommunication Industry. The 11th International Conference on Telecommunication Systems, Services, and Applications, At Lombok, Indonesia.

[37] Sigit Haryadi. (2017). Calculation of the Mobile Communication Competition using Haryadi Index. DOI: 10.13140/RG.2.2.15634.25280

[38] Sigit Haryadi. (2017). Harmony in Gradation and and its prospects as the Formula of Everything (First edition of posts: December 31, 2017). Researchgate. DOI: 10.13140/RG.2.2.19309.08169

[39] Sigit Haryadi. (2017). the Equality Correlation Method. Researchgate. DOI: 10.13140/RG.2.2.10443.80169.

[40] Sigit Haryadi. (2017). The Non-Intercept Linear Regression Method. Researchgate. DOI: 10.13140/RG.2.2.18721.71522

[41] Sigit Haryadi. (2017). The Fairness over Inequality Index: Unfairness is Disaster - a notebook of Sigit Haryadi. Researchgate. DOI: 10.13140/RG.2.2.34379.49449.

[42] Sigit Haryadi. (2017, December). Calculator for Measurement the Competition Index \& Level. Researchgate. DOI: 10.13140/RG.2.2.23626.26568

[43] Sigit Haryadi. (2017, December). Calculator for non intercept linear regression. Researchgate. DOI: 10.13140/RG.2.2.15761.94562.

[44] Sigit Haryadi. (2017, January). Calculation of the Income Equality Levels between Regions using the Haryadi Index. Researchgate. DOI: 10.13140/RG.2.2.36605.77282

[45] Sigit Haryadi. (2018, February). Applied Statistics for Assessment of the Regulation and Policy: case study in Telecommunication Industry. DOI: 10.13140/RG.2.2.15774.02884

[46] Sigit Haryadi; Dyah Rakhma Ariyanti. (October 2017). The Fairness of Resource Allocation and Its Impact on 5G Ultra-Dense Cellular Network Performance. The 11th International Conference on Telecommunication Systems, Services, and Applications, At Lombok, Indonesia.

[47] Westi Riani; Sigit Haryadi. (2017). CALCULATOR for the Government to make the Fair Policy of Tax Rates. Researchgate. DOI: 10.13140/RG.2.2.18550.50246. Available online at http://sigitharyadi.net/multidicipline/income-tax-rates-calculator-id/

[48] Westi Riani; Sigit Haryadi. (2017). The Method Of Tax Rate Determination Based On Fairness. Prosiding Seminar Nasional SNaPP2017, Bandung, Indonesia.

[49] Haryadi, S., \& Riani, W. (2018, March 12). Telecommunication Competition and Interconnection. Retrieved from osf.io/preprints/inarxiv/7tfqd

[50] Westi Riani; Sigit Haryadi. (2017). Prosiding SNaPP2017 "THE METHOD OF TAX RATE DETERMINATION BASED ON FAIRNESS". Conference: Seminar Nasional Penelitian dan PKM (SNaPP) 2017At: Bandung, Indonesia.

[51] Sigit Haryadi. (2017). Tantangan Untuk Menerapkan Haryadi Index pada Ilmu Fisika. Jurnal Pendidikan Fisika Sekolah Menengah. Jurnal Pendidikan Fisika Sekolah Menengah. Vol 
9 no 1 2017. ISSN: 1979-4959. Available at : https://www.researchgate.net/publication/316683866

[52] Westi Riani; Sigit Haryadi. (2016). Keterbatasan Indeks Gini sebagai Ukuran Ketimpangan Pendapatan dan Solusi Metoda Alternatif. Prosiding SNaPP: Sosial, Ekonomi, dan Humaniora. Tersedia di http://proceeding.unisba.ac.id/index.php/sosial/article/view/383

[53] Haryadi, S., \& Riani, W. (2018, March 19). Pengukuran Ketimpangan Indeks Pembangunan Manusia. Retrieved from osf.io/preprints/inarxiv/x9vjt

[54] Haryadi, S., \& Riani, W. (2018, March 19). Measurement of the Human Development Index Inequality. Retrieved from osf.io/preprints/inarxiv/5r42m

[55] Haryadi, Sigit. 2018. "Always Move to Seek Perfection: The New Equilibrium Index Calculation for the Science of Physics and Astronomy." INA-Rxiv. July 13. osf.io/preprints/inarxiv/8hrnb.

[56] Sigit Haryadi. (2018, October). Harmony in Gradation: The Formula for Everything. Obtained December 12, 2018, from https://www.haryadi.org/

[57] Sigit Haryadi. (2018, October). A New Equilibrium Index for the science of Physics and Astronomy. Obtained December 12, 2018, from https://www.haryadi.org/a-new-equilibriumindex/

[58] Sigit Haryadi. (2018, October). Formula for Everything, It's My Turn Trying to Make It. Obtained December 12, 2018, from https://www.haryadi.org/formula-for-everything-its-myturn-trying-to-make-it/

[59] Sigit Haryadi. (2018, October). Competition Level in the Industry. Obtained December 12, 2018, from https://www.haryadi.org/competition-level-in-the-industry/

[60] Sigit Haryadi. (2018, October). Competition Levels among Students. Obtained December 12, 2018, from https://www.haryadi.org/competition-levels-among-students-in-class/

[61] Sigit Haryadi. (2018, October). Consistency Test. Obtained December 12, 2018, from https://www.haryadi.org/consistency-test/

[62] Sigit Haryadi. (2018, October). Equality Correlation. Obtained December 12, 2018, from https://www.haryadi.org/equality-correlation/

[63] Sigit Haryadi. (2018, October). Fair Policy of Tax Rate. Obtained December 12, 2018, from https://www.haryadi.org/fair-policy-of-tax-rates/

[64] Sigit Haryadi. (2018, October). Fairness over Inequality. Obtained December 12, 2018, from https://www.haryadi.org/fairness-over-inequality/

[65] Sigit Haryadi. (2018, October). Income Equality. Obtained December 12, 2018, from https://www.haryadi.org/income-equality/

[66] Sigit Haryadi. (2018, October). Inequality of Human Development Index. Obtained December 12, 2018, from https://www.haryadi.org/inequality-of-human-development-index/

[67] Sigit Haryadi. (2018, October). Internet Service Equity. Obtained December 12, 2018, from https://www.haryadi.org/internet-service-equity/

[68] Sigit Haryadi. (2018, October). Linear Regression without Intercept. Obtained December 12, 2018, from https://www.haryadi.org/linear-regression-without-intercept/

[69] Sigit Haryadi. (2018, October). Modified Formula of Information Entropy. Obtained December 12, 2018, from https://www.haryadi.org/channel-cavity/

[70] Sigit Haryadi. (2018, October). Performance Simulation of 5G Cellular Network. Obtained December 12, 2018, from https://www.haryadi.org/performance-simulation-of-5gcellular-network/

[71] Sigit Haryadi. (2018, October). Smart Estimation ver-H-1-0. Obtained December 12, 2018, from https://www.haryadi.org/smart-estimation-ver-h-1-0/ 